\author{
О.М. Литвяк ${ }^{1}$, С.В. Комар ${ }^{2}$ \\ ${ }^{1}$ Національний університет цฺивільного захисту Украӥни, Харків \\ ${ }^{2}$ Харківський національний університет Повітряних Сил ім. I. Кожедуба, Харків
}

\title{
ОСОБЛИВОСТІ СТАТИЧНИХ ХАРАКТЕРИСТИК РЕГУЛЯТОРА ОБЕРТІВ ВІЛЬНОЇ ТУРБІНИ НАСОСА-РЕГУЛЯТОРА ТИПУ НР-3
}

\begin{abstract}
Представлені результати експериментальних досліджень статичних характеристик регулятора обертів вільної турбіни насоса-регулятора типу НР-3, призначеного для турбовального газотурбінного двигуна типу ТВ3-117. В результаті аналізу експериментальних статичних характеристик регулятора виявлені нелінійні ділянки. Нелінійність статичної характеристики регулятора може призводити до незадовільної роботи системи автоматичного регулювання двигуном. Показано, щяо статична характеристика регулятора обертів вільної турбіни є підтвердженням якості виготовлення або ремонту насосів-регуляторів типу НР-3 при приймально-здавальних випробуваннях.
\end{abstract}

Ключові слова: турбовальний газотурбінний двигун, насос-регулятор, регулятор обертів, статична характеристика, коливання обертів двигуна, гістерезис характеристики.

\section{Вступ}

Постановка проблеми. Часто при проведенні приймально-здавальних випробувань турбовальних двигунів типу ТВ3-117 на гідрогальмівних установках, рідше при експлуатації цих двигунів у складі силових установок вертольотів різних типів, фіксують несправності, які проявляються, як усталені коливання обертів роторів турбокомпресора (ТК) i вільної турбіни (ВТ) в області роботи регулятора обертів вільної турбіни (РОВТ). Вирішенням цієї проблеми, як правило, є заміна насоса-регулятора HР-3. Проте перевірка агрегатів за протоколом приймально-здавальних випробувань (ПЗВ) заводу виробника ДП ХМЗ “ФЭД”, включаючи повне розбирання і дефектацію деталей, не дозволяє виявити причини цієї несправності. Як уже було відмічено, коливання обертів роторів ТК і ВТ спостерігаються в області роботи РОВТ, призначеного для стабілізації усталених режимів роботи двигуна. На практиці вважається, що регулятор на усталеному режимі підтримує витрату палива незмінною і необхідною для роботи двигуна. Тому при приймальноздавальних випробуваннях агрегатів типу НР-3 на заводі виробнику основна увага приділяється тільки точкам настроювання насоса-регулятора, без перевірки і аналізу характеристики регулятора обертів вільної турбіни в цілому. В той же час слід зазначити, що на усталених режимах роботи регулятор, відповідно до характеристик, безперервно коригує (змінює) витрату палива, забезпечуючи парирування швидкозмінних зовнішніх збурень.

Таким чином, існує проблема дослідження статичних характеристик регулятора обертів вільної турбіни насоса-регулятора типу НР-3, призначеного для турбовального вертолітного ГТД ТВ3-117.

Аналіз останніх досліджень і публікацій. Регулятор, як і об'єкт регулювання, є невід'ємною частиною системи автоматичного регулювання (САР) i характеристики регулятора визначають динаміку поведінки САР на усталених режимах роботи.

Коливання обертів двигуна слід би віднести до динамічних (неусталених) режимів роботи. Проте під неусталеними режимами роботи авіаційних ГТД розуміється запуск, приймальність, і скидання газу [1-2]. Динаміка регуляторів режиму розглядається на етапах попереднього проектування САР.

У роботах [3-4] основна увага при дослідженні динаміки ГТД приділяється роботі автоматів приймальності та скидання газу. Розглядаються програми керування приймальністю і способи оптимізації роботи автоматів в різних умовах. Динаміка САР на усталених режимах не розглядається.

У [5] розглядаються нелінійні коливання параметрів газотурбінних двигунів, викликаних помпажом і зривними течіями в компресорі. У [6] розглядаються питання діагностики газотурбінних двигунів на основі спектрального аналізу коливань елементів двигуна. Питання причин розвитку автоколивань на усталених режимах роботи двигуна і характеристики регуляторів не розглядаються.

У роботах [7-8] розглядаються причини виникнення низькочастотних коливань при випробуваннях двигунів на гідрогальмівних установках. У [7] представлена модель розрахунку, збудження низькочастотних коливань в системі вимірів реактивного моменту високочастотними коливаннями тиску потоку рідини. Проте ця модель не дозволяє пояснити 
виникнення автоколивань параметрів двигуна або його нестійку роботу в області роботи РОВТ. У [8] відзначається, що можливими причинами виникнення низькочастотних коливань частоти обертання ВТ є взаємодія двигуна і гідрогальмівної установки, але до кінця ці причини авторам виявити не вдалося. У [9] розглядається числове моделювання течії в керуючому клапані гідроприводу регулятора. Дослідження представляють практичний інтерес, але використання отриманих авторами результатів обмежується числом кавітації і вимагає перевірки експериментом. У [10] представлена методика аналізу роботи регулятора за частотними характеристиками посилюючого каскаду. Ця методика також представляє інтерес, однак потребує значних затрат для виконання аналізу

Аналіз останніх досліджень і публікацій показав, що дослідженням реальних характеристик регуляторів паливо-регулюючих агрегатів не приділяється належної уваги. Це дозволяє зробити висновок про необхідність проведення поглиблених досліджень статичних характеристик реальних регулятоpiв.

\section{Метою статті $\epsilon$ :}

- експериментальне дослідження особливостей статичних характеристик регулятора обертів вільної турбіни насоса-регулятора типу НР-3, що впливають на динаміку роботи регулятора і сприяють розвитку автоколивань в системі автоматичного регулювання обертів вільної турбіни двигунів типу ТВ3-117;

- удосконалення методів діагностики якості виготовлення насосів регуляторів типу НР-3 на ранніх стадіях виробництва і ремонту;

- отримання нових даних що дозволять враховувати реальні характеристики РОВТ при математичному моделюванні динаміки силових установок вертольотів.

\section{Виклад основного матеріалу}

\section{Методика експериментальних досліджень}

Об'єктом дослідження є регулятор обертів вільної турбіни насоса-регулятора типу НР-3. Ставиться завдання провести експериментальні дослідження статичних характеристик РОВТ різних агрегатів 3 подальшим їх аналізом. Дослідження проводилися на паспортизованому стенді заводувиробника ДП ХМЗ “ФЭД”.

Характеристика РОВТ знімалася при середньому положенні важеля настроювання $\alpha_{B T}=66^{\circ}$.

Для виключення впливу регулятора обертів турбокомпресора на статичну характеристику РОВТ його настроювання повинне відповідати злітному режиму. Для цього важіль настроювання регулятора обертів ТК встановлюється в положення $\alpha_{p y d} \geq 85^{\circ}$.

Оберти ТК встановлюються відповідно до розрахункової точки РОВТ $n_{T K}=3740 \circ \sigma / x в$.

Для виключення впливу автомата приймальності на статичну характеристику РОВТ тиск, що імітує тиск за компресором, подається в агрегат рівним $P_{2}=9 \kappa 2 / c м^{2}$, а на електромагнітний клапан МКТ163 перенастроювання автомата приймальності подається живлення.

При проведенні експерименту оберти ВТ змінювалися плавно без провалів і зворотного ходу від максимального значення до мінімального i назад із затримкою в заданих точках не менше 10с.

Для проведення подальшого аналізу розглянемо розрахункову статичну характеристику РОВТ, показану на рис. 1.

\section{TB3-117}

РУКОВОДСТВО ПО ТЕХНИЧЕСКОЙ ЭНСПЛУАТАЦИИ

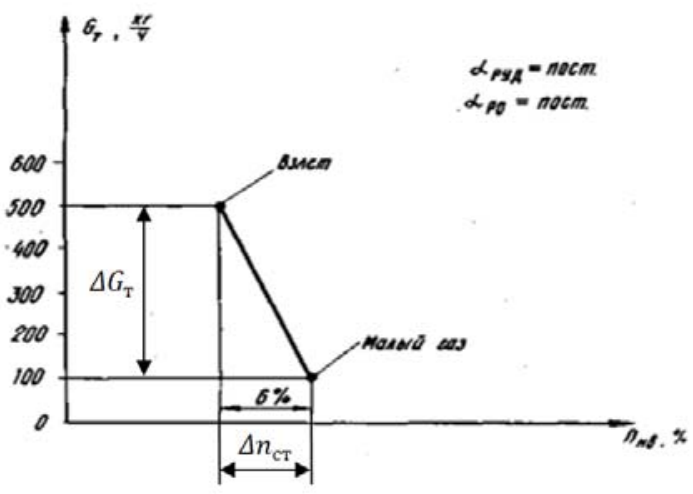

Рис. 1. Розрахункова статична характеристика РОВТ Джерело: розроблено авторами.

Як видно з рис. 1, розрахункова статична характеристика РОВТ у усьому діапазоні зміни обертів ВТ - лінійна.

Дійсна характеристика РОВТ дещо складніша за розрахункову, оскільки містить явно виражений гістерезис $\left(\Delta n_{\Gamma I C}\right)$ (рис. 2$)$, обумовлений наявністю сил тертя в гідроприводі основної дозуючої голки (ОДГ) насоса регулятора.

Суцільною лінією на рис. 2 показаний “прямий” хід ОДГ (збільшення витрати палива при зменшенні обертів ВТ). Пунктирною лінією показаний “зворотний” хід ОДГ (зменшення витрати палива при збільшенні обертів ВТ). Різниця обертів ВТ при прямому і зворотному ході ОДГ при заданій витраті палива називається гістерезисом. Згідно з протоколом приймально-здавальних випробувань (ПЗВ) заводу-виробника гістерезис POBТ $\Delta n_{\text {ГІС }}$ не повинен перевищувати 40 об/хв. 


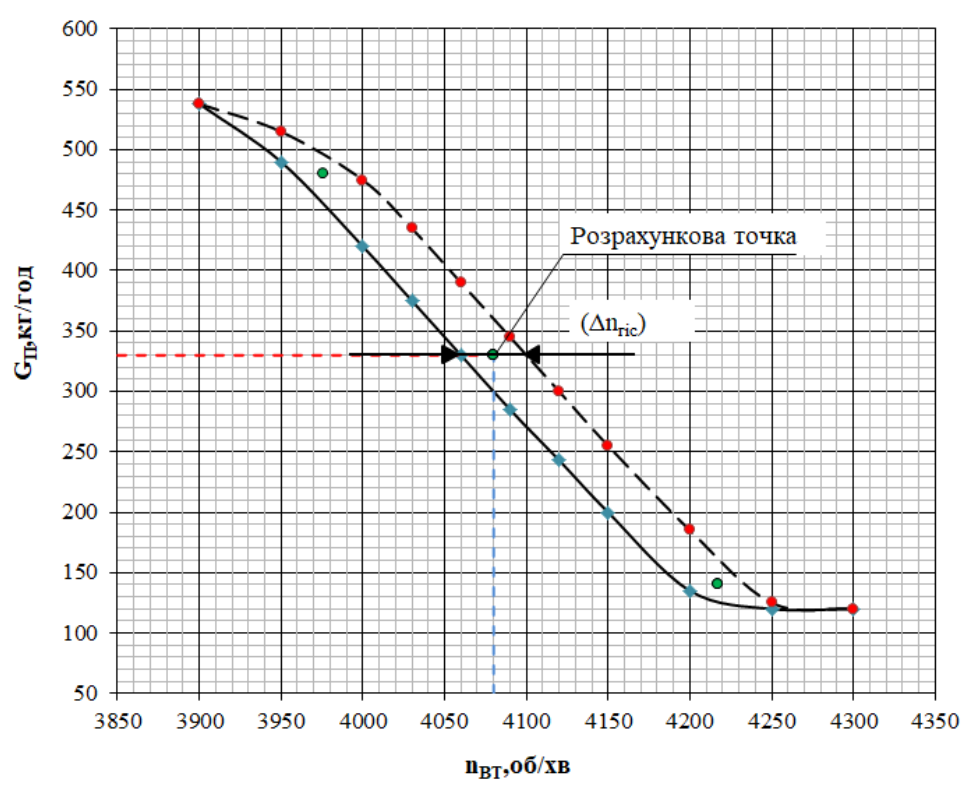

Рис. 2. Дійсна статична характеристика РОВТ Джерело: розроблено авторами.

На статичній характеристиці РОВТ показана розрахункова точка (РТ), яка відповідає другому крейсерському режиму роботи двигуна.

Відношення приросту витрати палива $\Delta G_{\Pi}$ до зміни обертів вільної турбіни $\Delta n_{B T}$ називається коефіцієнтом підсилення регулятора:

$$
K_{P O B T}=\frac{\Delta G_{\Pi}}{\Delta n_{B T}} .
$$

Величина зміни обертів РОВТ при заданій зміні витрати палива називається статизмом регулятора. Очевидно, що ці дві величини пов'язані простим співвідношенням:

$$
\Delta n_{B T}=\frac{\Delta G_{\Pi}}{\kappa_{P O B T}} .
$$

Згідно з протоколом ПЗВ ФЭД статизм РОВТ повинен знаходитися в межах (140...260) об/хв при зміні витрати палива на величину $\Delta G_{\Pi}=340$ кг/ год. Такий широкий діапазон зміни витрати палива не дозволяє досить точно визначити статизм РОВТ. Тому спочатку визначався коефіцієнт підсилення по двох сусідніх точках виміру (1), а потім визначався статизм РОВТ, приведений до даних протоколу ПЗВ

$$
\Delta n_{B T}=\frac{340}{K_{P O B T}} .
$$

Такий підхід дозволяе визначити дійсну величину статизма РОВТ в розрахунковій точці, а також визначити статизм в області підвищених і понижених витрат палива (у верхній і нижній частинах характеристики) при перенастроюваннях регулятора.

Таким чином, в результаті експерименту визначалися:

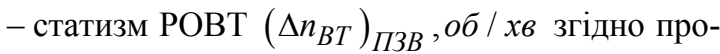
токолу ПЗВ;

- дійсна величина статизма РОВТ
$\left(\Delta n_{B T}\right)_{P}$, об / хв в межах розрахункової точки;

- гістерезис характеристики $\left(\Delta n_{\Gamma Г C}\right)_{P}$, об / хв в межах розрахункової точки;

- оберти ВТ при розрахунковому значенні витрати палива $G_{\Pi}=330 \kappa 2 /$ год, які повинні відповідати розрахунковому значенню $n_{B T}=4080 \pm 20$ oб / $x$..

\section{Результати досліджень та їх аналіз}

Як показали дослідження, дійсні статичні характеристики реальних РОВТ агрегатів типу НР- 3 сильно відрізняються один від одного навіть в межах допустимих значень протоколу ПЗВ і мають характерні особливості: різні значення статизма, гістерезису, а також відхилення від лінійності - розриви і злами.

На рис. 3-8 представлені статичні характеристики РОВТ різних агрегатів з характерними особливостями.

На рис. 3 показана статична характеристика POBT агрегату P-111.

Аналіз статичної характеристики:

- статизм $\left(\Delta n_{B T}\right)_{\Pi з B}=154$ oб / xв ;

- статизм $\left(\Delta n_{B T}\right)_{P}=1140 б / x_{B}$;

- гістерезис $\left(\Delta n_{\text {ГІС }}\right)_{P}=31$ об / хв .

Формально характеристика РОВТ задовольняє вимогам протоколу ПЗВ, проте реальна величина статизма регулятора менше допустимого значення.

Малий статизм РОВТ (великий коефіцієнт підсилення) знижує запас стійкої роботи САР, що сприяє розвитку автоколивань, а при певних значеннях динамічних параметрів двигуна процес регулювання може стати нестійким. 


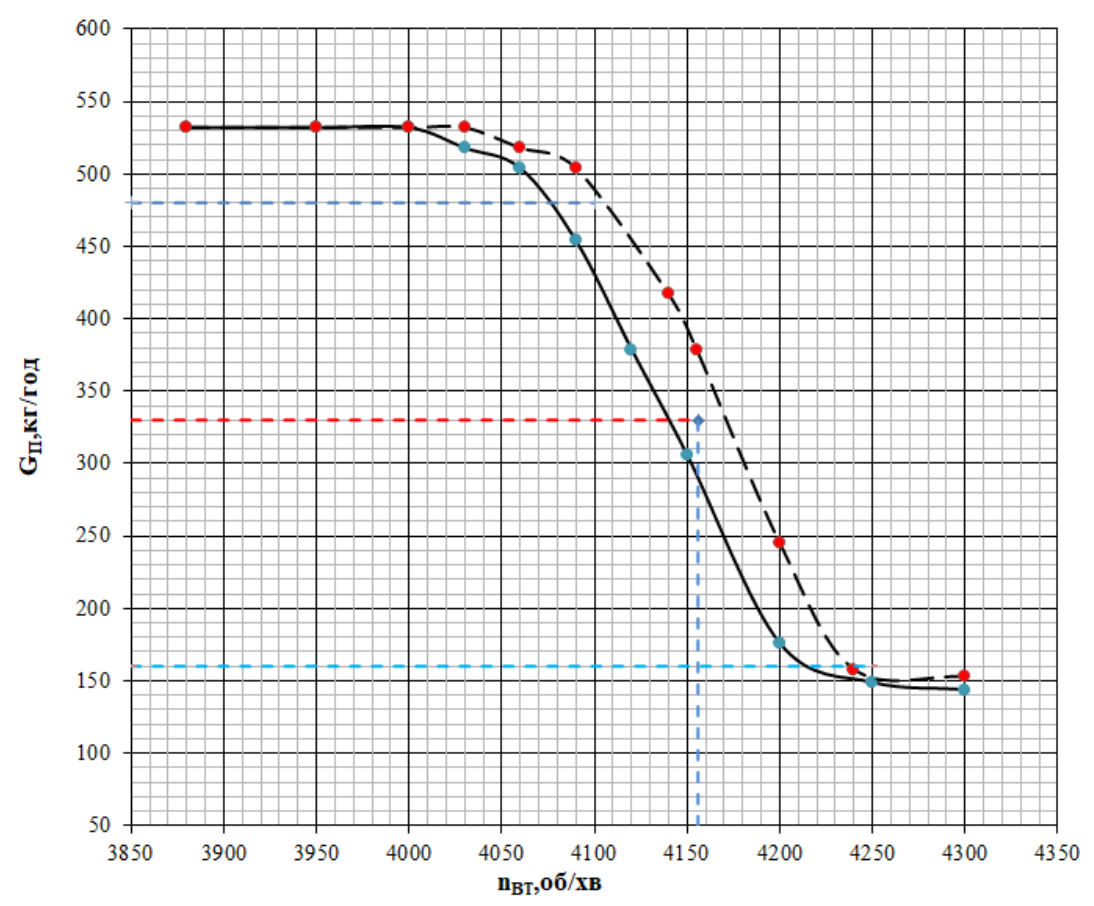

Рис. 3. Характеристика РОВТ агрегату Р-111 Джерело: розроблено авторами.

3 рис. 3 також видно, що оберти ротора ВТ при розрахунковій витраті палива вищі за норму (4157об/хв), що так само не відповідає вимогам протоколу ПЗВ.

Висновок - агрегат схильний до розвитку автоколивань при моторних випробуваннях.

Важливу роль в демпфіруванні автоколивань грає гістерезис характеристики регулятора. У протоколі приймально-здавальних випробувань заводувиробника обумовлено лише максимальне значення гістерезису характеристики РОВТ (не більше за 40об/хв). В той же час можуть бути агрегати 3 нульовим (рис. 4) і навіть від'ємним (рис. 5) гістерезисом.

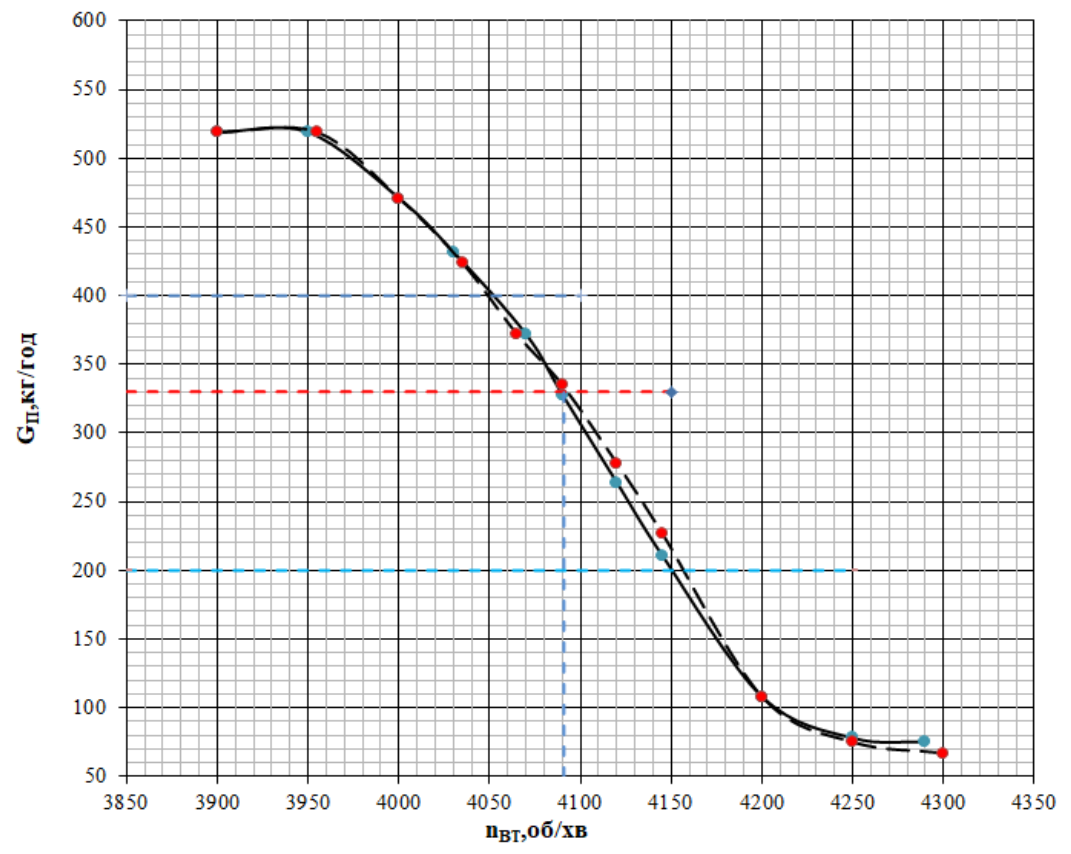

Рис. 4. Характеристика РОВТ агрегату Р-569

Джерело: розроблено авторами.

Гістерезис статичної характеристики обумовлений силами тертя в гідроприводі основної дозуючої голки. А оскільки сила тертя завжди направлена проти руху, то нульовий або від'ємний гістерезис статичної характеристики РОВТ надалі був інтерпретований при аналізі, як дефект агрегату. 
Аналіз статичної характеристики РОВТ агрегату Р-569 (рис. 4):

$$
\begin{aligned}
& - \text { статизм }\left(\Delta n_{B T}\right)_{П з в}=117 \text { об / хв } \\
& - \text { статизм }\left(\Delta n_{B T}\right)_{P}=155 \text { об / хв } \\
& \text { - гістерезис }\left(\Delta n_{\Gamma I C}\right)_{P}=0 \text { об / хв }
\end{aligned}
$$

Формально характеристика задовольняє вимогам протоколу ПЗВ, але, як показали подальші дослідження, агрегат з такою характеристикою регулятор обертів вільної турбіни схильний до розвитку автоколивань ВТ при моторних випробуваннях.

На рис. 5 представлена статична характеристи- ка РОВТ агрегату Р-300.

Аналіз статичної характеристики:

- статизм $\left(\Delta n_{B T}\right)_{П з в}=166$ об / хв ;

- статизм $\left(\Delta n_{B T}\right)_{P}=119$ об / хв ;

- гістерезис $\left(\Delta n_{\Gamma І С}\right)_{P}=-9$ об / хв .

Від'ємний гістерезис явно свідчить про наявність дефекту в системі керування ОДГ. Агрегат схильний до автоколивань.

На рис. 6 представлена статична характеристика агрегату Р-562.

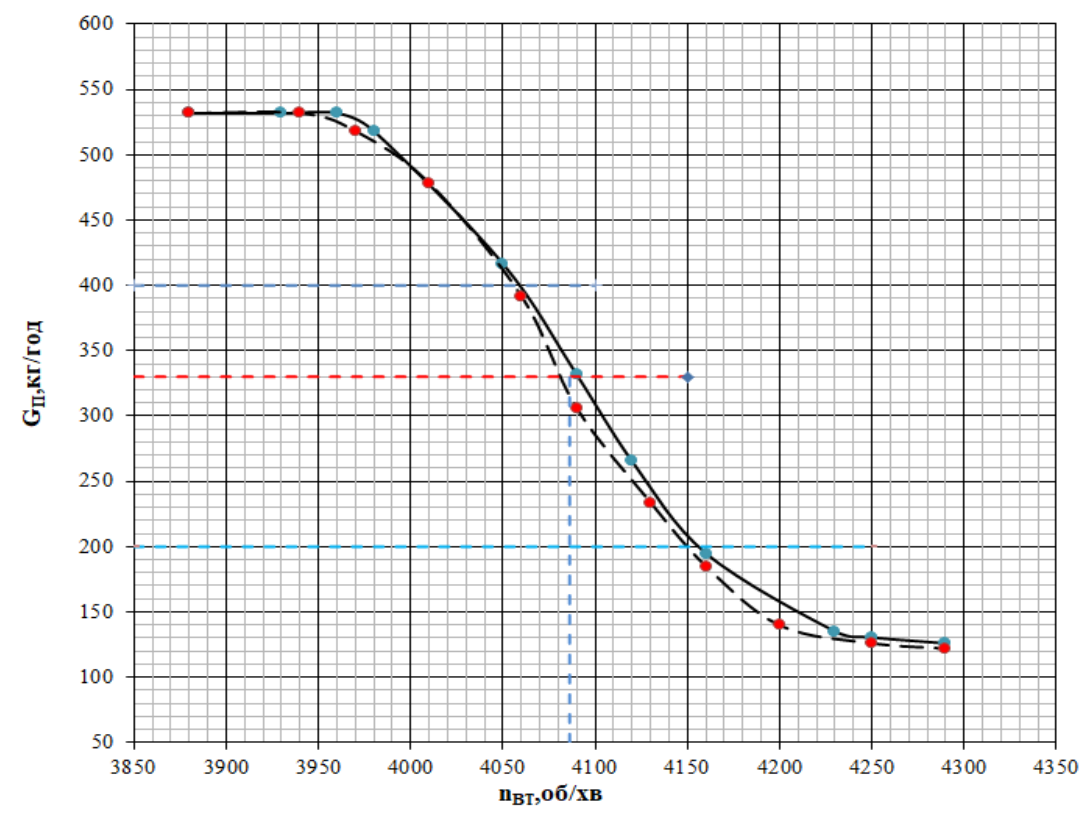

Рис. 5. Характеристика РОСТ агрегата Р-300 Джерело: розроблено авторами.

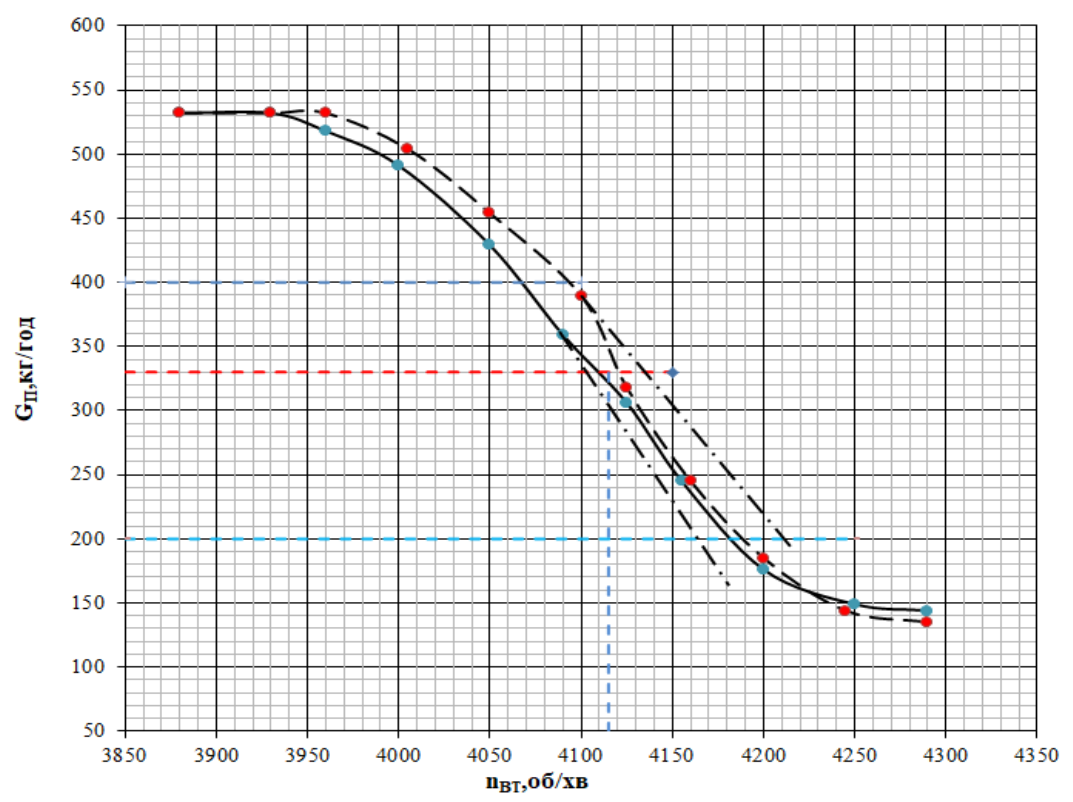

Рис. 6. Характеристика РОСТ агрегата Р-562 Джерело: розроблено авторами.

На статичній характеристиці видно різке відхилення лінії “прямого” ходу від лінійної залежності (показано пунктиром). Оскільки точки знімалися 3 дискретним кроком, то така зміна витрати палива 
може свідчити про розрив характеристики і ступінчасту зміну витрати палива в цій області. Розрив характеристики регулятора сприяє розвитку автоколивань в САР [11-12].

Аналіз статичної характеристики РОВТ агрегату P-562:

$$
\begin{aligned}
& - \text { статизм }\left(\Delta n_{B T}\right)_{\Pi з B}=168 \text { об / } x в ; \\
& - \text { статизм }\left(\Delta n_{B T}\right)_{P}=103 \text { об / хв }
\end{aligned}
$$

- гістерезис $\left(\Delta n_{\Gamma І C}\right)_{P}=27$ об / хв .

В області розрахункової точки статизм РОВТ менше допустимого значення, а характеристика має розрив при прямому ході ОДГ. Агрегат схильний до автоколивань.

На рис. 7 представлена статична характеристика агрегату Р-566.

На рис. 8 представлена статична характеристика агрегату Р-394.

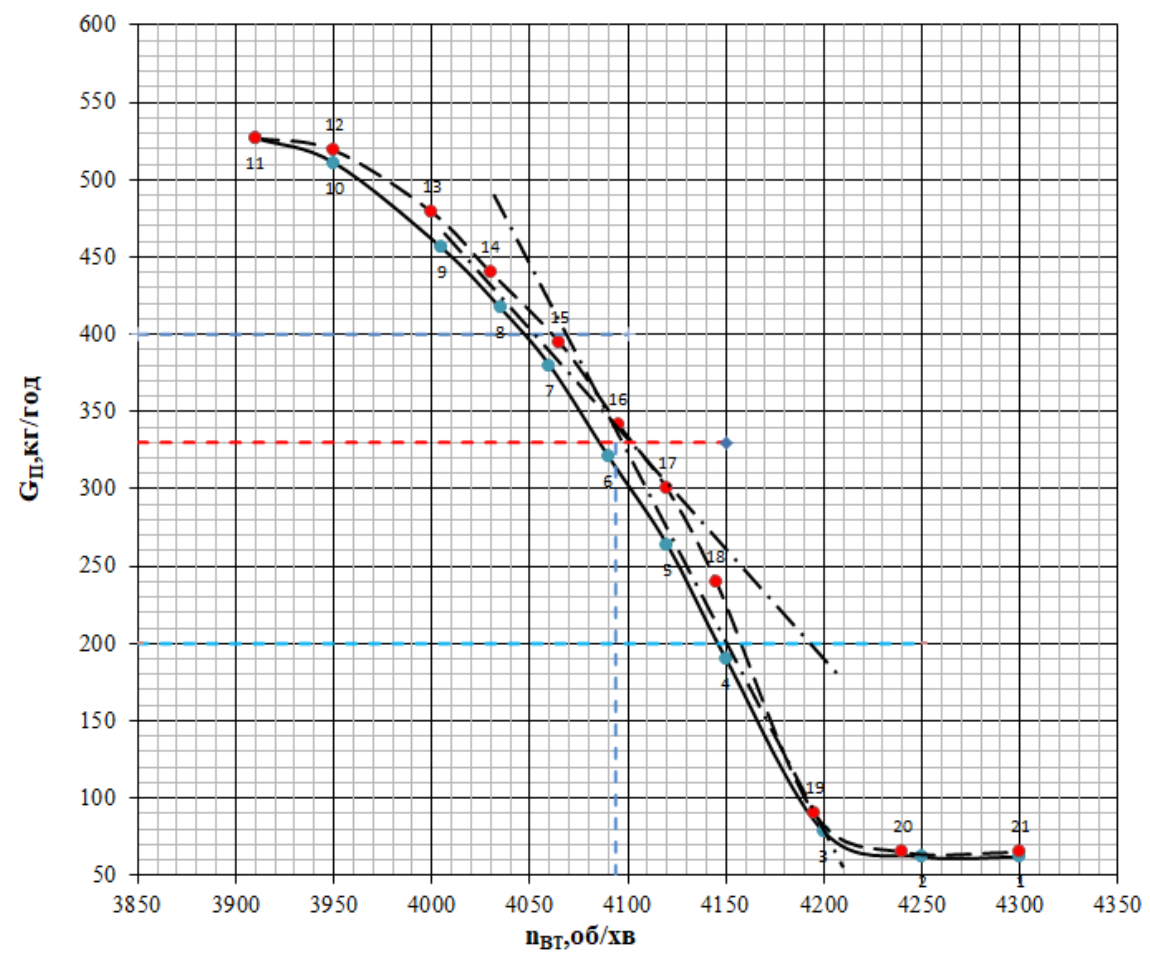

Рис. 7. Характеристика РОСТ агрегата Р-566 Джерело: розроблено авторами.

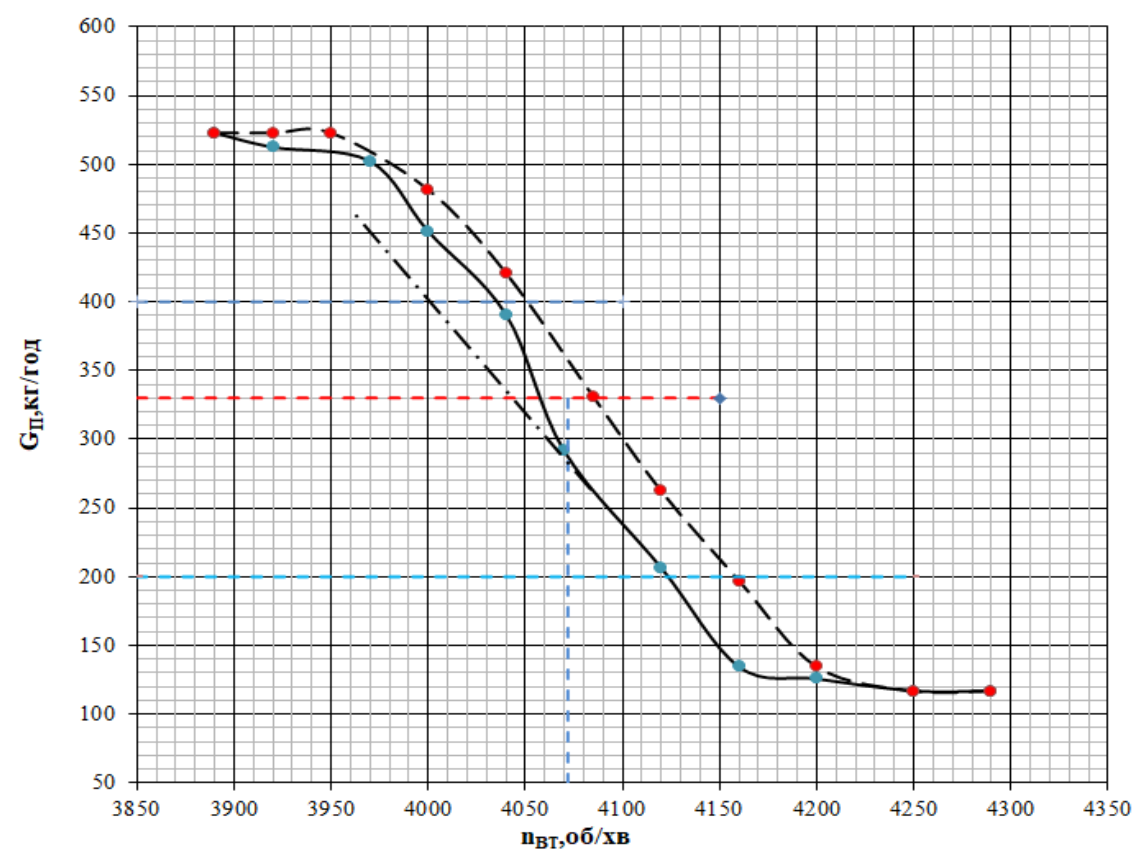

Рис. 8. Характеристика РОСТ агрегата Р-394 Джерело: розроблено авторами. 
Характеристика зазнає зламу в області розрахункової точки. Під зламом характеристики розуміється ступінчаста зміна кута нахилу. Для наочності пунктирними лініями нанесені усереднені лінійні ділянки верхньої і нижньої частини характеристики.

Аналіз статичної характеристики:

- статизм $\left(\Delta n_{B T}\right)_{\Pi з B}=167$ об / хв;

- статизм $\left(\Delta n_{B T}\right)_{B E P X}=194 o б / x в$;

- статизм $\left(\Delta n_{B T}\right)_{\text {НИз }}=143$ об / хв ;

- гістерезис $\Delta n_{\Gamma І С}=12$ об / хв .

В області розрахункової точки статизм РОВТ різко зменшується і наближається до мінімально допустимого значення. Ступінчаста зміна коефіцієнта підсилення регулятора свідчить про дефект в системі дозування палива, що може призводити до розвитку автоколивань.

\section{Статистика моторних випробувань}

В табл. 1 представлені значення параметрів POBТ в розрахунковій точці агрегатів, які успішно пройшли випробування на моторних стендах “Мотор Січ”.

Таблиця 1

Параметри РОВТ справних агрегатів

\begin{tabular}{|c|c|c|}
\hline № & $\left(\Delta n_{B T}\right)_{P}$, об/хв & $\left(\Delta n_{\text {ГІС }}\right)_{P}$, об/хв \\
\hline 1 & 206 & 25 \\
\hline 2 & 242 & 40 \\
\hline 3 & 187 & 20 \\
\hline 4 & 164 & 35 \\
\hline 5 & 213 & 15 \\
\hline 6 & 172 & 16 \\
\hline 7 & 152 & 20 \\
\hline 8 & 190 & 35 \\
\hline 9 & 185 & 35 \\
\hline 10 & 162 & 16 \\
\hline 11 & 244 & 10 \\
\hline
\end{tabular}

Джерело: розроблено авторами.

3 табл. 1 видно, що агрегати, які мають достатній гістерезис статичної характеристики РОВТ та пологу характеристику, не схильні до розвитку коливань параметрів двигунів при моторних випробуваннях.
В табл. 2 представлені значення параметрів POBT в розрахунковій точці агрегатів, які не пройшли випробування на моторних стендах "Мотор Січ” через розвиток коливань параметрів двигунів.

Таблиця 2

Параметри РОВТ дефективних агрегатів

\begin{tabular}{|c|c|c|}
\hline № & $\left(\Delta n_{B T}\right)_{P}$, об/хв & $\left(\Delta n_{\Gamma \text { ГС }}\right)_{P}$, об/хв \\
\hline 1 & 185 & 0 \\
\hline 2 & 125 & 0 \\
\hline 3 & 142 & 0 \\
\hline 4 & 177 & 7 \\
\hline 5 & 222 & 5 \\
\hline 6 & 171 & 10 \\
\hline 7 & 163 & 13 \\
\hline 8 & 147 & 10 \\
\hline 9 & 178 & 16 \\
\hline 10 & 186 & 16 \\
\hline 11 & 153 & 3 \\
\hline
\end{tabular}

Джерело: розроблено авторами.

3 табл. 2 видно, що агрегати, які мають мале значення статизму РОВТ та недостатнє значення величини гістерезису, схильні до розвитку коливань параметрів двигунів при моторних випробуваннях.

\section{Висновки}

1. Розроблена методика визначення і аналізу статичної характеристики РОВТ агрегатів типу НР-3 на випробувальних стендах заводу-виробника для прогнозування розвитку автоколивань при моторних випробуваннях (зараз ця методика використовується на заводі-виробнику ДП ХМЗ “ФЭД”, як обов'язкова умова приймально-здавальних випробувань агрегатів типу НР-3).

2. На підставі аналізу великої кількості експериментальних даних виявлені характерні особливості статичної характеристики РОВТ: розриви, злами, нульовий або від'ємний гістерезис, які слід віднести до дефектів агрегату.

3. Показано, що визначення статизма РОВТ згідно з протоколом ПЗВ заводу-виробника не відбиває дійсної картини поведінки регулятора при моторних випробуваннях агрегатів типу НР-3.

\section{Список літератури}

1. Гуревич О.С. Системы автоматического управления авиационными газотурбинными двигателями // О.С. Гуревич. - М.: Торус Пресс, 2011. -207 с.

2. Гуревич О.С. Системы автоматического управления авиационными газотурбинными двигателями / О.С. Гуревич // Труды центрального института авиационного моторостроения. - 2010. - № 1346. - 264 с.

3. Сосунов А.В. Неустановившиеся режимы работы авиационных газотурбинных двигателей / А.В. Сосунов, Ю.А. Литвинов. - М.: Машиностроение, 1975. - 215 с.

4. Дедеш В.Т. Идентификация систем управления авиационных газотурбинных двигателей / В.Т. Дедеш. - М.: Машиностроение, 1984. - 193 с.

5. Письменный И.Л. Многочастотные нелинейные колебания в турбинном двигателе / И.Л. Письменный. - М.: Машиностроение, 1987. - 128 с. 
6. Ткачешак Н.В. Діагностика газотурбінного двигуна на основі перетворення Фур'є / Н.В. Ткачешак // Технические науки. - 2018. - № 1(11). - C. 53-61. https://doi.org/10.30888/2415-7538.2018-11-01-030.

7. Van den Braembussche R.A.Dynamic Stability of a water brake dynamometer / R.A. van den Braembussche, H. Malys // Journal of Engineering for Gas Turbines and Power. - 1998. - № 120. - P. 89-96.

8. Экспериментальное исследование колебательных процессов при испытаниях турбовинтового двигателя на гидротормозной установке / А.Г. Гимадиев, В.А. Букин, П.И. Грещняков, А.В. Уткин // Сборник материалов докладов международной научно-технической конференции. - Самара, 22-24 июня 2016 г., Ч. 1. - С. 20-21.

9. Xinbei L. Performance and Flow Field Analysis of Flapper Deflection Servo Valve / L. Xinbei, L. Songjing, V. Lomakin // Global Fluid Power Society Phd Symposium. - Samara, 18-20 July 2018. $\quad$ - P. $\quad 1-6$. https://doi.org/10.1109/GFPS.2018.8472394.

10. Frequency analysis and compensation of valve stiction in cascade control loops / Li Chen, M.A.A. Shoukat Choudhury, B. Huang, F. Qian // Journal of Process Control. - 2014. - № 24. - P. 1747-1760. https://doi.org/10.1016/j.jprocont.2014.09.009.

11. Маркианов Л.И. Автоматика авиационных газотурбинных двигателей / Л.И. Маркианов. - Х.: ХВВАИКУ, 1984. $-325 \mathrm{c}$.

12. Штода А.В. Автоматика авиационных двигателей / А.В. Штода. - М.: ВВИА им.проф. Н.Е. Жуковского, $1968 .-$ $458 \mathrm{c}$.

\section{Відомості про авторів:}

\section{Литвяк Олександр Миколайович}

кандидат технічних наук доцент доцент Національного університету цивільного захисту України,

Харків, Україна

http://orcid.org/0000-0002-0242-1859

\section{Комар Сергій Володимирович} кандидат технічних наук доцент доцент Харківського національного університету Повітряних Сил ім. І. Кожедуба, Харків, Україна https://orcid.org/0000-0002-8961-2614

\section{Information about the authors:}

Alexander Litvyak
Candidate of Technical Sciences Associate Professor
Senior Lecturer of National University
of Civil Protection of Ukraine,
Kharkiv, Ukraine
http://orcid.org/0000-0002-0242-1859
Sergii Komar
Candidate of Technical Sciences Associate Professor
Senior Lecturer of Ivan Kozhedub Kharkiv National
Air Force University,
Kharkiv, Ukraine
https://orcid.org/0000-0002-8961-2614

\title{
ОСОБЕННОСТИ СТАТИЧЕСКИХ ХАРАКТЕРИСТИК РЕГУЛЯТОРА ОБОРОТОВ СВОБОДНОЙ ТУРБИНЫ НАСОСА-РЕГУЛЯТОРА ТИПА НР-3
}

\author{
А.Н. Литвяк, С.В. Комар
}

Представлены результаты экспериментальных исследований статических характеристик регулятора оборотов свободной турбины насоса-регулятора типа НР-3, предназначенного для турбовального газотурбинного двигателя типа ТВ3-117. В результате анализа экспериментальных статических характеристик регулятора выявлены нелинейные участки. Нелинейность статической характеристики регулятора может приводить к неудовлетворительной работе системы автоматического регулирования двигателем. Показано, что статическая характеристика регулятора оборотов свободной турбины является подтверждением качества изготовления или ремонта насосов-регуляторов типа НР-3 при приемо-сдаточных испытаниях.

Ключевые слова: турбовальный газотурбинный двигатель, насос-регулятор, регулятор оборотов, статическая характеристика, колебания оборотов двигателя, гистерезис характеристики.

\section{FEATURES OF THE STATIC CHARACTERISTICS OF THE SPEED REGULATOR OF A FREE TURBINE OF THE PUMP-REGULATOR OF THE NR-3 TYPE}

\section{A. Litviak, S. Komar}

The results of experimental studies of the static characteristics of the speed controller of a free turbine of the pump-controller of the HP-3 type, intended for a turboshaft gas turbine engine of the TB3-117 type, are presented. When conducting acceptance tests of engines on hydraulic brake units, malfunctions are recorded, which manifest themselves as steady fluctuations in the speed of the turbocharger and free turbine rotors in the area of the free turbine regulator. Checking the pump-regulators according to the manufacturer's acceptance test report does not reveal the cause of this malfunction. As a result of the analysis of experimental static characteristics, it was revealed that the actual static characteristics of real regulators are very different from each other even within the acceptable values of the acceptance test protocol and have characteristic features: different values of statism, hysteresis, as well as deviations from linearity - breaks and fractures. Small statism of the regulator (large gain) reduces the margin of stable operation of the automatic control system, which contributes to the development of self-oscillations, and at certain values of the dynamic parameters of the engine, the control process may become unstable. The hysteresis of the static characteristic of the regulator plays an important role in vibration damping. It should be positive, since it is conditiones by the frictional forces in the hydraulic drive of the main metering needle. Therefore, a zero or negative hysteresis of the static characteristic of the regulator indicates a defect in the unit, which is confirmed by a tendency to self-oscillation. Non-linearity of the static characteristic of the regulator can lead to unsatisfactory operation of the automatic control system by the engine. It is shown that the static characteristic of the speed controller of a free turbine is a confirmation of the quality of manufacture or repair of pump-regulators of the HP-3 type during acceptance tests.

Keywords: turboshaft gas turbine engine, pump-regulator, speed controller, static characteristic, engine speed fluctuations, characteristic hysteresis. 